\title{
DMB Machine Reliability Analysis Through Failure Mode Effect Analysis and Reliability Block
}

\section{Analisa Keandalan DMB Machine Melalui Failure Mode Effect Analysis dan Reliability Block Diagram}

\author{
Annisa Indah Pratiwi', Boyman Sihombing ${ }^{1}$, Muhamad Sayuti ${ }^{1}$, Nugraha Pradana ${ }^{1}$, Dewih Adetia ${ }^{1}$ \\ ${ }^{1}$ Jurusan Teknik Industri, Fakultas Teknik dan Ilmu Komputer \\ Universitas Buana Perjuangan Karawang, Jl. HS. Ronggowaluyo Telukjambe Timur Karawang 41361 \\ email : annisa.indah@ubpkarawang.ac.id \\ doi: https://doi.org/10.31315/opsi.v14i1.4745
}

Received: $9^{\text {th }}$ May 2021; Revised: 27th May 2021; Accepted: $21^{\text {st }}$ June 2021;

Available online: $24^{\text {th }}$ June 2021; Published regularly: June 2021

\begin{abstract}
The production process is carried out continuously, it will result in decreased machine capability. When a component on a machine is damaged resulting in the production process being interrupted, the machine's performance depends on the Reliability of the machine or the component. The DMB machine is a sorting machine at PT Etex Building Performance Indonesia, because it is the main machine in the production process and DMB has a high downtime in 2019. Failure Mode effect And Analysis, aims to determine the machine failure factor. Reliability Block Diagram, to determine machine reliability. The results of research with FMEA are Pneumatic with RPN value 60, Decelerator value RPN 64, Accelerator value RPN 56, Hydraulic Table Safety Lock value RPN 48, Roller value RPN 48 Bearing Lifting value RPN 36, Sensor Transfer Dolly value RPN 48, Motor Transfer Template RPN value 36, the Suction Cup is the component that has the lowest RPN value with a value of 30, from the Reliability Block Diagram (RBD) calculation, the DMB machine reliability opportunity value is obtained including $88.42 \%$ of the production process for 23 hours, $42.25 \%$ of the process for 161 hours of operation., and decreased by $2.70 \%$ when used for 674 hours of operation. Recommended action is to perform maintenance actions with the type of daily care and weekly maintenance.
\end{abstract}

Keywords: failure, preventive maintenance, reliability

\begin{abstract}
ABSTRAK
Proses produksi dilakukan secara terus menerus maka akan mengakibatkan kemampuan mesin menjadi menurun. Saat komponen pada mesin mengalami kerusakan mengakibatkan proses produksi terganggu, maka kinerja mesin bergantung pada Reliability mesin atau komponen tersebut. Mesin DMB adalah mesin sortir di PT Etex Building Performance Indonesia, Karena merupakan mesin utama dalam proses produksi dan DMB memiliki downtime yang tinggi pada tahun 2019. Failure Mode effect And Analysis, bertujuan menentukan faktor kegagalan mesin. Reliability Block Diagram, untuk menentukan kehandalan mesin. Hasil Penelitian dengan FMEA adalah Peunematic nilai RPN 60, Deccelarator nilai RPN 64, Accelarator nilai RPN 56, Hydrolic Table Safety Lock nilai RPN 48, Roller nilai RPN 48 Bearing Lifting nilai RPN 36, Sensor Transfer Dolly nilai RPN 48, Motor Transfer Template nilai RPN 36, Suxtion Cup adalah komponen yang memiliki nilai RPN paling rendah dengan nilai 30 , dari perhitungan Reliability Block Diagram (RBD) didapat nilai peluang kehandalan mesin DMB diantaranya $88,42 \%$ proses produksi selama 23 jam, 42,25\% proses selama 161 jam operasi, dan menurun sebesar 2,70\% apabila digunakan selama 674 jam operasi, Rekomendasi tindakan adalah melakukan tindakan perawatan dengan jenis Perawatan Harian Dan Perawatan mingguan.
\end{abstract}

Kata Kunci: failure, preventive maintenance, reliability 


\section{PENDAHULUAN}

Menurut Yanti dan Susi (2018) "ditengah ketidakstabilan perekonomian dan semakin tajamnya persaingan di dunia industri, maka merupakan suatu keharusan bagi suatu perusahaan untuk lebih meningkatkan efisiensi kegiatan operasinya. Salah satu hal yang mendukung kelancaran kegiatan operasi pada suatu perusahaan adalah kesiapan mesin-mesin produksi dalam melaksanakan tugasnya. Untuk mencapai hal itu diperlukan adanya suatu sistem perawatan yang baik." Yanti dan Susi (2018) juga menyebutkan bahwa "kegiatan perawatan mempunyai peranan yang sangat penting, karena selain sebagai pendukung beroperasinya sistem agar lancar sesuai dengan apa yang dikehendaki, kegiatan perawatan juga dapat meminimalkan biaya atau kerugian-kerugian yang ditimbulkan karena adanya kerusakan-kerusakan mesin." maka cara apapun akan dilakukan untuk mendapatkan hasil yang maksimal Untuk mendukung tujuan-tujuan tersebut, Menurut $\mathrm{H}$ Pranoto (2015), berpendapat bahwa "perlu adanya penjaminan terhadap kualitas dalam hal pemeliharaan sistem produksi dan adanya perlindungan terhadap lingkungan dan keselamatan ditempat kerja, maka dari itu proses produksi dari pengelolaan objek teknis perusahaan tersebut perlu diidentifikasi agar dukungan proses terhadap objek teknis tersebut dapat tercapai." Seringkali, pada pelaksaan proses produksi perusahaan terjadi product rejects yang diakibatkan oleh up awal, kerusakan pada objek teknis perusahaan, pemeliharaan objek teknis yang terjadwal kemudian mengalami downtime sehingga menyebabkan tenaga kerja lembur dan berakibat biaya pemeliharaan yang tinggi pada mesin yang dimiliki oleh perusahaan.

Pada Tabel 1 walaupun mesin DMB sudah memiliki jadwal preventive menunjukan bahwa masih banyak perbaikan yang tidak sesuai dengan rencana dan menyebabkan downtime mesin yang tinggi. Maka penelitian harus bisa memperhitungkan kapasitas mesin atau part yang tepat dan dilakukannya preventive yang tepat untuk menghindari pergantian part yang mendadak dan tentunya membutuhkan waktu saat melakukan perbaikan. maka agar mencegah timbulnya kerusakan-kerusakan pada saat mesin sedang beroperasi, diperlukan suatu sistem maintanance (pemeliharaan) yang dapat
Tabel 1. Total Stop Machine DMB

TOTAL STOP MACHINE DMB FEBRUARI 2019 FEBRUARI 2020

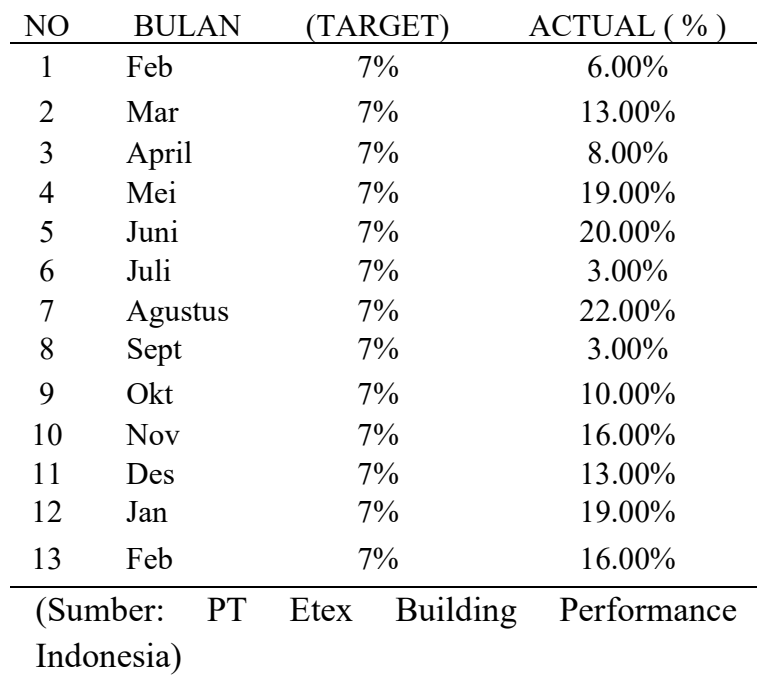

memprediksi kapan kerusakan berpeluang akan terjadi. Berdasarkan kutipan dari Hadi Pranoto (2015), dalam bukunya yang berjudul "Reability Centered Maintenance" yaitu "Tantangan utama yang dihadapi oleh orang-orang perawatan saat ini adalah tidak hanya belajar tentang apa saja dari Teknik-teknik perawatan prediktif, tetapi untuk memutuskan mana yang bermanfaat dan mana yang tidak didalam organisasinya. Kurniawan (2013), Sehingga Reability Engineering merupakan sistem pemeliharaan yang tepat dilakukan pada mesin DMB. Maka dengan menggunakan FMEA mesin DMB bertujuan dapat menentukan faktor kegagalan mesin. Dan Reliability Block Diagram (RBD), untuk menentukan kehandalan mesin DMB sehingga dapat dilakukan perbaikan/pergantian part diwaktu preventif dimana komponen/part yang berpotensi mengganggu proses sehingga diharapkan mampu meminimalisasi kerusakan yang terjadi secara tiba-tiba pada saat mesin sedang beroperasi.

\section{METODE}

Penelitian ini dilakukan di sebuah perusahaan yang berada di Karawang yaitu PT Etex Building Performance Indonesia dan dilakukan di departemen perawatan mesin (maintenance). Sedangkan objek yang akan di lakukan penelitian adalah mesin DMB (mesin produksi) dimesin ini terdapat downtime mesin yang tinggi yang menyebabkan proses produksi 
terganggu dan merugikan perusahaan. Penelitian ini dimulai dari bulan Februari 2019 hingga Februari 2020.

Jenis data yang digunakan terdiri dari:

1. Data Primer

Berikut adalah tabel observasi saat melakukan penelitian:

1. Penulis menemukan bahwa saat perbaikan waktu terbuang saat maintenance datang ketika terdapat masalah. Karena maintenance berada di workshop dan warkshop itu berada didasar pengambilan keputusan untuk aktifitas perawatan.

2. Data perbaikan dimasukkan ke dalam tabel database perbaikan.

3. Saat maintenance sebelum melakukan perbaikan maintenance order (MO) maka harus dibuatkan terlebih dahulu

4. Tidak ada pengolahan data lebih lanjut

2. Data Sekunder

Data ini merupakan data pokok peneliti sabagai studi analisa dalam menentukan nilai keandalan mesin DMB (Dipiling Machine Before Autoclave). Data tersebut meliputi bukubuku yang relevan, peraturan, laporan kegiatan, photo, video dan data penelitian yang relevan untuk mengetahui permasalahan yang terjadi.

Berikut metode pengumpulan data dalam penelitian, yaitu:

1. Studi Pustaka

2. Observasi

3. Wawancara

Adapun kerangka pemikiran pada proses pengolahan data dijelaskan pada Gambar 1 dan diagram penelitian yang dilakukan dalam penelitian ini diilustrasikan pada Gambar 2 .

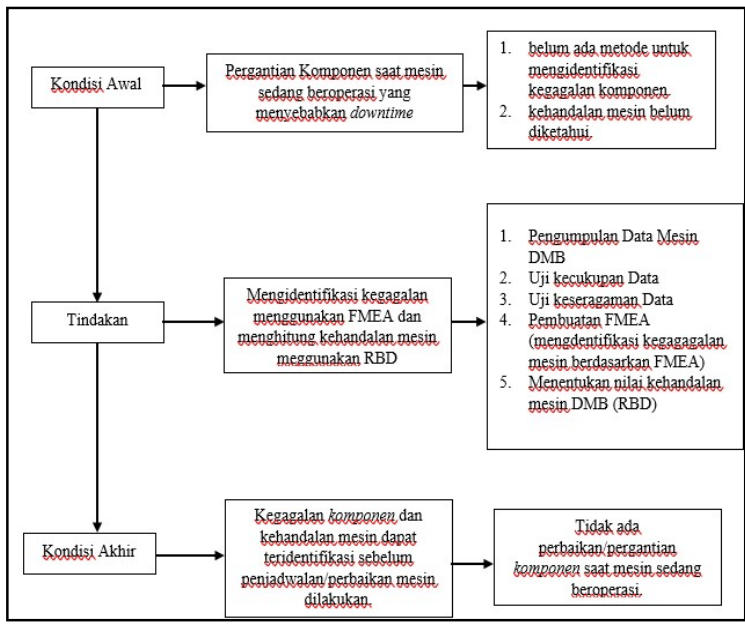

Gambar 1. Kerangka Pemikiran

\subsection{Failure Modes and Effect Analysis (FMEA)}

Menurut Liu et al (2011), FMEA adalah "sebuah metode analisis resiko yang sepenuhnya dimulai dari bawah keatas dengan menentukan potensi kegagalan yang akan diketahui melalui metode tersebut." Dan Menurut Rasyindo (2015), FMEA adalah "Mode kegagalan suatu keadaan yang dapat menyebabkan kegagalan fungsional. Sehingga apabila mode kegagalan dapat diketahui maka dampak kegagalan dari suatu sistem dapat digambarkan. Maka mode kegagalan dapat digunakan untuk menentukan konsekuensi dan memutuskan apa yang akan dilakukan untuk mengantisipasi, mencegah, mendeteksi, dan memperbaiki mesin berdasarkan dari analisa Failure Mode And Effect Analysis." Menurut Hapster (2016) penerapan FMEA memiliki tujuan ialah

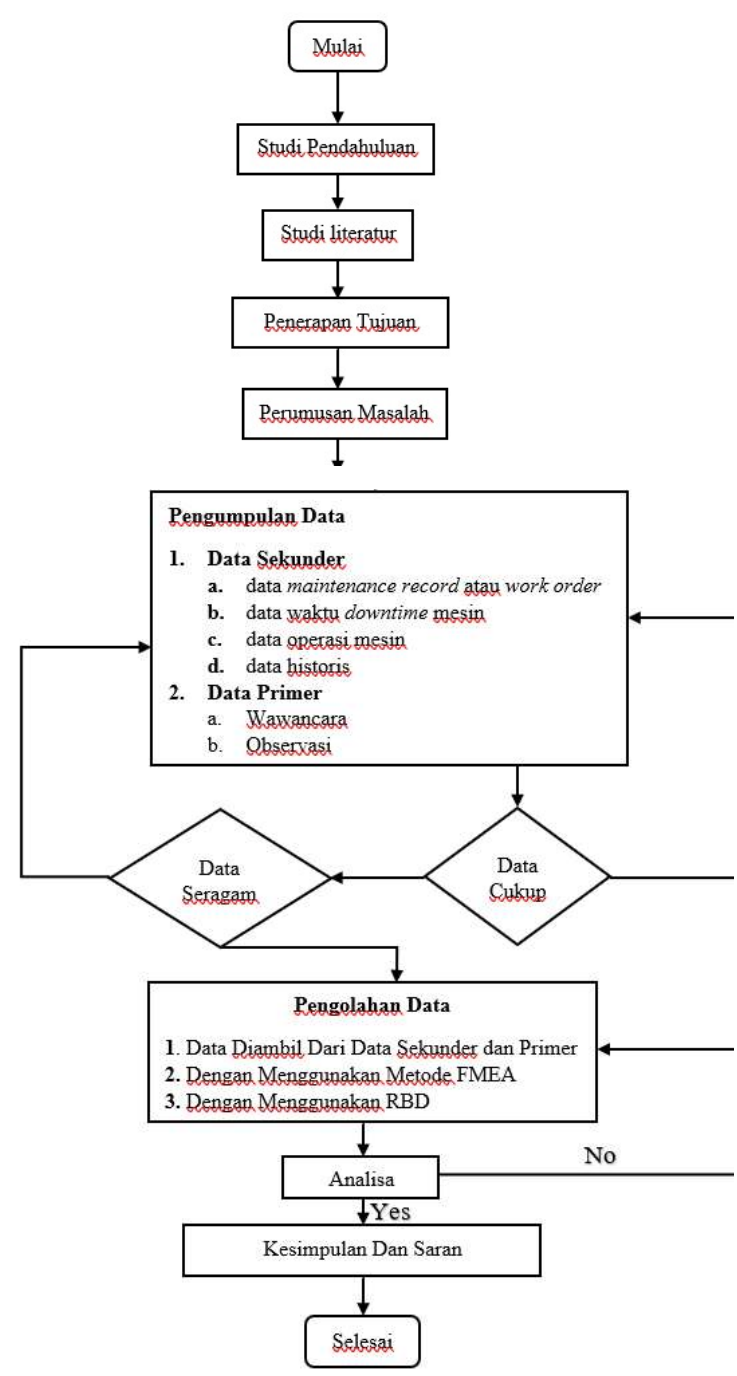

Gambar 2. Diagram Flowchart Penelitian 
"mencegah masalah terjadi pada proses dan produk itu sendiri. Dengan menggunakan metode FMEA peneliti dapat memprediksi terhadap suatu bagian atau proses yang mungkin mengalami kegagalan dalam proses produksi berlangsung dan memastikan proses produksi berjalan sesuai target yang ingin dicapai dikarenakan mesin yang dijadikan penelitian memiliki waktu proses yang panjang dan membutuhkan metode yang dapat mengidentifikasi masalah-masalah yang terjadi saat proses berlangsung.

\subsection{Menggunakan Metode Reliability Blok Diagram (RBD)}

Setelah mendapatkan nilai RPN dari mesin DMB maka kita dapat menentukan komponen mana yang harus memerlukan jadwal perawatan. Setelah itu peneliti akan menentukan part mana saja yang akan dicari nilai reliability-nya, part yang akan dicari nilainya adalah part yang sering mengalami kerusakan. Maka selanjutnya membuat jadwal perawatan komponen dengan menghitung MTBF Data yang diperlukan untuk menghitung nilai MTBF adalah data operasi mesin saat beroperasi (waktu optimal) dan data waktu kegagalan (jumlah kerusakan yang terjadi) mesin yang ada di DMB machine.

\section{HASIL DAN PEMBAHASAN}

\subsection{Perhitungan Pembuatan Tabel Failure Mode Effect Analysis}

Penentukan nilai FMEA dijabarkan pada Tabel 2. Saat melakukan pembuatan tabel FMEA harus diperhatikan juga kegagalan atau pun kerusakan untuk mempermudah operator mengidentifikasi faktor kegagalan pada objek penelitian. Setelah teridentifikasi mesin atau part mana saja yang sering mengalami kegagalan proses maka selanjutnya akan ditentukan Rating dari severity, occurance, detection dengan menggunakan microsoft Excel dan nilai tersebut didapat dari nilai historis kerusakan mesin DMB yang terjadi. nilai RPN sangat penting karena merupakan bagian penting dari FMEA yang berkisar berkisar 1-1000.

\subsection{Perhitungan Reliability Block Diagram}

Maka untuk medapatkan nilainya, yang dilakukan adalah mendapatkan data diperusahaan, data tersebut ialah berupa kerusakan apa saja yang pernah terjadi, didalam data tersebut didapat waktu
Tabel 2. Jumlah Kerusakan Komponen Mesin

\begin{tabular}{|c|c|c|c|}
\hline \multicolumn{4}{|c|}{ DMB } \\
\hline No & Komponen & $\begin{array}{c}\text { Jumlah } \\
\text { Kegagalan }\end{array}$ & Lokasi Kegagalan \\
\hline 1 & Suxtion Cup & 10 & $\begin{array}{l}\text { Fiber Cement } \\
\text { Gripper (DMB) }\end{array}$ \\
\hline 2 & $\begin{array}{l}\text { Bearing } \\
\text { Lifting }\end{array}$ & 2 & $\begin{array}{l}\text { Fiber Cement } \\
\text { Gripper }(\mathrm{DMB})\end{array}$ \\
\hline 3 & Peunematic & 5 & $\begin{array}{l}\text { Fiber Template } \\
\text { Gripper }(\mathrm{DMB})\end{array}$ \\
\hline 4 & $\begin{array}{l}\text { Hydrolic } \\
\text { Table Safety } \\
\text { Lock }\end{array}$ & 3 & $\begin{array}{l}\text { Dolly } \\
\text { (DMB) }\end{array}$ \\
\hline 5 & $\begin{array}{l}\text { Motor } \\
\text { Transfer } \\
\text { Template }\end{array}$ & 2 & $\begin{array}{l}\text { Template Transfer } \\
\text { Track (DMB) }\end{array}$ \\
\hline 6 & Roller & 3 & $\begin{array}{l}\text { Template Transfer } \\
\text { Track(DMB) }\end{array}$ \\
\hline 7 & Accelarator & 4 & $\begin{array}{l}\text { Template Transfer } \\
\text { Track(DMB) }\end{array}$ \\
\hline 8 & Decelarator & 4 & $\begin{array}{l}\text { Template Transfer } \\
\text { Track (DMB) }\end{array}$ \\
\hline 9 & $\begin{array}{l}\text { Sensor } \\
\text { Transfer } \\
\text { Dolly }\end{array}$ & 3 & $\begin{array}{l}\text { Dolly } \\
\text { (DMB) }\end{array}$ \\
\hline
\end{tabular}

kegagalan/kerusakan. Setelah itu di tentukan berapa lama mesin tersebut bekerja, sesuai data yang sudah didapat mesin DMB beroperasi dengan total 6727 jam mesin bekerja. Maka setelah itu tentukan nilai mana saja yang akan dicari nilai reliability nya, pada mesin DMB terdapat kerusakan pada Suxtion Cup, Bearing Lifting, Peunematic, Hydrolic Table Safety Lock, Motor Transfer Template, Roller, Accelarator, Decelarator, Sensor Transfer Dolly.

\begin{tabular}{|c|c|c|c|c|}
\hline $\begin{array}{l}\text { Fungsi } \\
\text { mesin }\end{array}$ & komponen & $\begin{array}{l}\text { Efek potensi dari } \\
\text { kegagalan }\end{array}$ & $\begin{array}{l}\text { S } \\
\text { E } \\
\text { V }\end{array}$ & Penyebab kegagalan \\
\hline \multirow{9}{*}{$\begin{array}{c}\text { DMB } \\
\text { machine } \\
\text { sebagai } \\
\text { mesin } \\
\text { sortir }\end{array}$} & Suxtion Cup & Template jatuh & 10 & Umur Pakai yang sudah habis \\
\hline & Bearing Lifting & $\begin{array}{l}\text { Mesin tidak dapat } \\
\text { transfer template }\end{array}$ & 2 & $\begin{array}{l}\text { Tersumbat kotoran debu, proses } \\
\text { manual }\end{array}$ \\
\hline & Peunematic & Tidak dapat proses & 5 & Rentan Terhadap goncangan \\
\hline & $\begin{array}{l}\text { Hydrolic Table } \\
\text { Safety Lock }\end{array}$ & $\begin{array}{l}\text { Tidak dapat transfer } \\
\text { produk }\end{array}$ & 3 & $\begin{array}{l}\text { Bengkok, patah dan rentan pada } \\
\text { getaran }\end{array}$ \\
\hline & $\begin{array}{l}\text { Motor } \\
\text { Transfer } \\
\text { Template }\end{array}$ & Mesin stop & 2 & $\begin{array}{l}\text { Terkena kotoran dan umur pakai yang } \\
\text { sudah habis }\end{array}$ \\
\hline & Roller & $\begin{array}{l}\text { Template berpotensi } \\
\text { nabrak }\end{array}$ & 3 & Part gompal dan rusak \\
\hline & Accelarator & $\begin{array}{l}\text { Template tidak bisa di } \\
\text { transfer }\end{array}$ & 4 & Retak akibat terus proses \\
\hline & Decelarator & $\begin{array}{l}\text { Template jatuh akibat } \\
\text { position tidak pas }\end{array}$ & 4 & Rentan terhadap getaran \\
\hline & $\begin{array}{l}\text { Sensor } \\
\text { Transfer Dolly }\end{array}$ & $\begin{array}{l}\text { Tidak bisa transfer } \\
\text { produk yang selesai } \\
\text { sortir }\end{array}$ & 3 & Umur Pakai yang sudah habis \\
\hline
\end{tabular}

Gambar 2. FMEA DMB Machine 
Adapun rumus untuk menghitung nilai Mean Time Between Failure (MTBF) sebagai berikut:

$$
\text { MTBF }=\frac{\text { operation time }}{\text { failure }} \text { Maka : }
$$

Sumber : Ramesh (2012)

MTBF Suxtion Cup $=\frac{\mathbf{6 7 2 7} \mathbf{~ j a m}}{\mathbf{1 0}}=672.7 \mathrm{jam}$

MTBF Bearing Lifting $=\frac{\mathbf{6 7 2 7} \mathbf{~ j a m}}{\mathbf{2}}=3363.5 \mathrm{jam}$

MTBF Peuneumatic $=\frac{\mathbf{6 7 2 7} \mathbf{~ j a m}}{\mathbf{5}}=1345.4 \mathrm{jam}$

MTBF Hydrolic Table Safety Lock $=\frac{\mathbf{6 7 2 7} \text { jam }}{\mathbf{3}}$ $=2242.3 \mathrm{jam}$

MTBF Motor Transfer Template $=\frac{\mathbf{6 7 2 7} \mathbf{j a m}}{2}=$ $3363.5 \mathrm{jam}$

MTBF Roller $=\frac{\mathbf{6 7 2 7} \mathbf{j a m}}{\mathbf{3}}=2242.3 \mathrm{jam}$

MTBF Accelarator $=\frac{6727 ~ j a m}{4}=1681.7 \mathrm{jam}$

MTBF Decelarator $=\frac{\mathbf{6 7 2 7} \mathbf{j a m}}{\mathbf{4}}=1681.7 \mathrm{jam}$

MTBF Sensor Transfer Dolly $=\frac{\mathbf{6 7 2 7} \mathbf{j a m}}{\mathbf{3}}=$ 2242.3 jam

\subsection{Failure Rate}

Setelah mendapatkan Nilai MTBF maka selanjutnya adalah menghitung laju kegagalan (Failure Rate). ( $\lambda$-lamda) maka menggunakan rumus sebagai berikut:

$$
\lambda=\frac{1}{\mathrm{MTBF}}
$$

Sumber : Ramesh (2012)

$\lambda$ Suxtion Cup $=\frac{1}{672.7}=0.001486$

Kerusakan/jam

$\lambda$ Bearing Lifting $=\frac{1}{3363,5}=0.0002973$

Kerusakan/jam

$\lambda$ Peuneumatic $=\frac{1}{1345,4}=0.0007432$

Kerusakan/jam

$\lambda$ Hydrolic Table Safety Lock $=\frac{1}{2242,3}=$

0.0004459 Kerusakan/jam

$\lambda$ Motor Transfer Template $=\frac{1}{3363,5}=$

0.0002973 Kerusakan/jam

$\lambda$ Roller $=\frac{1}{2242,3}=0.0004459$ Kerusakan $/ \mathrm{jam}$

$\lambda$ Accelarator $=\frac{1}{1681,7}=0.0005946$

Kerusakan/jam $\lambda$ Decelarator $=\frac{1}{1681,7}=0.0005946$

Kerusakan/jam

$\lambda$ Sensor Transfer Dolly $=\frac{1}{2242,3}=0.0004459$

Kerusakan/jam

\subsection{Menghitung Keandalan Komponen DMB}

Perhitungan Reliability part/komponen pada mesin DMB akan dilakukan menurut jam operasi mesin, dalam menghitung keandalan part/komponen mesin DMB peneliti mengambil data operating time mesin pada bulan Februari 2019 dimana mesin beroperasi selama 477 jam dan didapat 1 hari mesin beroperasi selama 23 jam. Maka peneliti mengambil 23 jam (1 sehari), 161 jam (7 Hari), 322 (14 Hari), dan 477 jam (21 Hari). Maka keandalan masing-masing part/komponen dapat dihitung sebagai berikut:

1. Kehandalan Komponen Suxtion Cup Perhitungan berdasarkan 23 jam operating machine dijelaskan pada Tabel 3.

$$
\begin{aligned}
& \mathbf{R}=\boldsymbol{e}^{-(\boldsymbol{\lambda} \times \boldsymbol{t})} \\
& \mathbf{R}=\boldsymbol{e}^{-(\mathbf{0 , 0 0 1 4 8 6 \times 2 3 )}} \\
& \mathbf{R}=0.9663 \times 100 \% \\
& \mathbf{R}=96.63 \%
\end{aligned}
$$

2. Kehandalan Komponen Bearing Lifting Perhitungan berdasarkan 23 jam operating machine dijelaskan pada Tabel 4.

$$
\begin{aligned}
& \mathbf{R}=\boldsymbol{e}^{-(\boldsymbol{\lambda} \times \boldsymbol{t})} \\
& \mathbf{R}=\boldsymbol{e}^{-(0,0002973 \times \mathbf{2 3})} \\
& \mathbf{R}=0.9931 \times 100 \% \\
& \mathbf{R}=99.31 \%
\end{aligned}
$$

Tabel 3. Kehandalan Komponen Suxtion Cup

\begin{tabular}{ccc}
\hline No & $\begin{array}{c}\text { Waktu Operasi } \\
\text { Mesin (Jam) }\end{array}$ & $\begin{array}{c}\text { Kehandalan } \\
\text { Komponen (R) }\end{array}$ \\
\hline 1 & 23 & $96.63 \%$ \\
2 & 161 & $78.72 \%$ \\
3 & 322 & $61.97 \%$ \\
4 & 477 & $49.22 \%$
\end{tabular}


3. Kehandalan Komponen Pneumatic Perhitungan berdasarkan 23 jam operating machine dijelaskan pada Tabel 5.

$$
\begin{aligned}
& \mathbf{R}=\boldsymbol{e}^{-(\boldsymbol{\lambda} \times \boldsymbol{t})} \\
& \mathbf{R}=\boldsymbol{e}^{-(0,0007432 \times \mathbf{2 3})} \\
& \mathbf{R}=0.9830 \times 100 \% \\
& \mathbf{R}=98.30 \%
\end{aligned}
$$

4. Kehandalan Komponen Hydrolic Table Perhitungan berdasarkan 23 jam operating machine dijelaskan pada Tabel 6 .

$\mathbf{R}=\boldsymbol{e}^{-(\lambda \times t)}$

$\mathbf{R}=\boldsymbol{e}^{-(0,0004459 \times 23)}$

$\mathbf{R}=0.9897 \times 100 \%$

$\mathbf{R}=98.97 \%$

5. Kehandalan Komponen Motor Transfer Template

Perhitungan berdasarkan 23 jam operating machine dijelaskan pada Tabel 7 .

$\mathbf{R}=\boldsymbol{e}^{-(\lambda \times t)}$

$\mathbf{R}=\boldsymbol{e}^{-(0,0002973 \times 23)}$

$\mathbf{R}=0.9931 \times 100 \%$

$\mathbf{R}=99.31 \%$

6. Kehandalan Komponen Roller

Perhitungan berdasarkan 23 jam operating machine dijelaskan pada Tabel 8 .

$\mathbf{R}=\boldsymbol{e}^{-(\lambda \times t)}$

$\mathbf{R}=\boldsymbol{e}^{-(0,0004459 \times 23)}$

$\mathbf{R}=0.9897 \times 100 \%$

$\mathbf{R}=98.97 \%$

7. Kehandalan Komponen Accelarator Perhitungan berdasarkan 23 jam operating machine dijelaskan pada Tabel 9.

$\mathbf{R}=\boldsymbol{e}^{-(\lambda \times \boldsymbol{t})}$

$\mathbf{R}=\boldsymbol{e}^{-(0,0005946 \times 23)}$

$\mathbf{R}=0.9864 \times 100 \%$

$\mathbf{R}=98.64 \%$

8. Kehandalan Komponen Deccelarator Perhitungan berdasarkan 23 jam operating machine dijelaskan pada Tabel 10 .

$\mathbf{R}=\boldsymbol{e}^{-(\lambda \times \boldsymbol{t})}$
Tabel 4. Kehandalan Komponen Bearing Lifting

\begin{tabular}{ccc}
\hline No & Waktu Operasi Mesin (Jam) & $\begin{array}{c}\text { Kehandalan } \\
\text { Komponen (R) }\end{array}$ \\
\hline 1 & 23 & $99.31 \%$ \\
2 & 161 & $95.32 \%$ \\
3 & 322 & $90.87 \%$ \\
4 & 477 & $86.77 \%$ \\
\hline
\end{tabular}

Tabel 5. Kehandalan Komponen Pneumatic

\begin{tabular}{ccl}
\hline No & $\begin{array}{c}\text { Waktu Operasi Mesin } \\
\text { (Jam) }\end{array}$ & $\begin{array}{c}\text { Kehandalan } \\
\text { Komponen (R) }\end{array}$ \\
\hline 1 & 23 & $98.30 \%$ \\
2 & 161 & $88.72 \%$ \\
3 & 322 & $78.71 \%$ \\
4 & 477 & $70.15 \%$ \\
\hline
\end{tabular}

Tabel 6. Kehandalan Komponen Hydrolic Table

\begin{tabular}{ccc}
\hline No & $\begin{array}{c}\text { Waktu Operasi } \\
\text { Mesin (Jam) }\end{array}$ & $\begin{array}{c}\text { Kehandalan } \\
\text { Komponen (R) }\end{array}$ \\
\hline 1 & 23 & $98.97 \%$ \\
2 & 161 & $93.07 \%$ \\
3 & 322 & $86.62 \%$ \\
4 & 477 & $80.84 \%$ \\
\hline
\end{tabular}

Tabel 7. Kehandalan Komponen Motor Transfer Template

\begin{tabular}{ccc}
\hline No & $\begin{array}{c}\text { Waktu Operasi } \\
\text { Mesin (Jam) }\end{array}$ & $\begin{array}{c}\text { Kehandalan } \\
\text { Komponen (R) }\end{array}$ \\
\hline 1 & 23 & $99.31 \%$ \\
2 & 161 & $95.32 \%$ \\
3 & 322 & $90.87 \%$ \\
4 & 477 & $86.77 \%$ \\
\hline
\end{tabular}

Tabel 8. Kehandalan Komponen Roller

\begin{tabular}{ccc}
\hline No & $\begin{array}{c}\text { Waktu Operasi } \\
\text { Mesin (Jam) }\end{array}$ & $\begin{array}{c}\text { Kehandalan } \\
\text { Komponen (R) }\end{array}$ \\
\hline 1 & 23 & $98.97 \%$ \\
2 & 161 & $93.07 \%$ \\
3 & 322 & $86.62 \%$ \\
4 & 477 & $80.84 \%$ \\
\hline
\end{tabular}

Tabel 9. Kehandalan Komponen Accelarator

\begin{tabular}{ccc}
\hline No & $\begin{array}{c}\text { Waktu Operasi Mesin } \\
\text { (Jam) }\end{array}$ & $\begin{array}{c}\text { Kehandalan } \\
\text { Komponen (R) }\end{array}$ \\
\hline 1 & 23 & $98.64 \%$ \\
2 & 161 & $90.87 \%$ \\
3 & 322 & $82.57 \%$ \\
4 & 477 & $75.30 \%$ \\
\hline
\end{tabular}

Tabel 10. Kehandalan Komponen Deccelarator

\begin{tabular}{ccc}
\hline No & $\begin{array}{c}\text { Waktu Operasi Mesin } \\
(\mathrm{Jam})\end{array}$ & $\begin{array}{c}\text { Kehandalan } \\
\text { Komponen (R) }\end{array}$ \\
\hline 1 & 23 & $98.64 \%$ \\
2 & 161 & $90.87 \%$ \\
3 & 322 & $82.57 \%$ \\
4 & 477 & $75.30 \%$ \\
\hline
\end{tabular}




$$
\begin{aligned}
& \mathbf{R}=\boldsymbol{e}^{-(0,0005946 \times 23)} \\
& \mathbf{R}=0.9864 \times 100 \% \\
& \mathbf{R}=98.64 \%
\end{aligned}
$$

9. Kehandalan Komponen Sensor Transfer Dolly

Perhitungan berdasarkan 23 jam operating machine dijelaskan pada Tabel 11.

$$
\begin{aligned}
& \mathbf{R}=\boldsymbol{e}^{-(\lambda \times \boldsymbol{t})} \\
& \mathbf{R}=\boldsymbol{e}^{-(0,0004459 \times \mathbf{2 3})} \\
& \mathbf{R}=0.9897 \times 100 \% \\
& \mathbf{R}=98.97 \%
\end{aligned}
$$

\subsection{Menghitung Keandalan System DMB}

Maka untuk perhitungan system pada mesin DMB akan dilakukan berdasarkan operasi dan keseluruhan part/komponen yang mengalami kegagalan/kerusakan pada mesin DMB, peneliti mengambil sample operating time mesin pada bulan Februari 2019 dimana mesin beroperasi selama 477 jam dan didapat 1 hari mesin beroperasi selama 23 jam. Maka penulis mengambil 23 jam (1 sehari), 161 jam (1 minggu), 322 (14 Hari), dan 477 jam (21 hari). Perhitunganya adalah sebagai berikut:

1. Perhitungan Berdasarkan 1 hari (23 jam) operasi machine DMB

DMB Machine berdasarkan 23 jam operasi dapat dihitung sebagai berikut :

$$
\begin{aligned}
& \lambda \mathrm{e}=\sum_{i=1}^{n} \lambda \\
& \lambda \mathbf{e}=(0.001486+0.0002973+ \\
& 0.0007432+0.0004459+0.0002973+ \\
& 0.0004459+0.0005946+0.0005946+ \\
& 0.0004459) \\
& \lambda \mathbf{e}=0.0053507 \\
& \mathbf{R s}=\boldsymbol{e}^{-(\mathbf{0 , 0 0 5 3 5 0 7 \times 2 3 )}} \\
& \mathbf{R s}=0.8842 \times 100 \% \\
& \text { Rs }=88.42 \%
\end{aligned}
$$

Berdasarkan Tabel 13, maka didapat nilai dari kehandalan mesin DMB adalah sebagai berikut: $88.42 \%$ apabila proses produksi berjalan selama 23 jam operasi, $42.25 \%$ apabila proses produksi berjalan 161 jam operasi, dan menurun sebesar $7.70 \%$ apabila digunakan selama 477 jam operasi.
Tabel 11. Kehandalan Komponen Sensor Transfer Dolly

\begin{tabular}{ccc}
\hline No & $\begin{array}{c}\text { Waktu Operasi } \\
\text { Mesin (Jam) }\end{array}$ & $\begin{array}{c}\text { Kehandalan } \\
\text { Komponen (R) }\end{array}$ \\
\hline 1 & 23 & $98.97 \%$ \\
2 & 161 & $93.07 \%$ \\
3 & 322 & $86.62 \%$ \\
4 & 477 & $80.84 \%$ \\
\hline
\end{tabular}

Tabel 12. Kehandalan Komponen System DMB

\begin{tabular}{clc}
\hline No & \multicolumn{1}{c}{ Komponen } & Laju Kegagalan $(\lambda)$ \\
\hline 1 & Suxtion Cup & 0.001486 \\
2 & Bearing Lifting & 0.0002973 \\
3 & Peunematic & 0.0007432 \\
4 & Hydrolic Table & 0.0004459 \\
& Safety Lock & \\
5 & Motor Transfer & 0.0002973 \\
& Template & \\
6 & Roller & 0.0004459 \\
7 & Accelarator & 0.0005946 \\
8 & Decelarator & 0.0005946 \\
9 & Sensor Transfer & 0.0004459 \\
& Dolly & \\
\hline
\end{tabular}

Tabel 13. Kehandalan DMB machine

\begin{tabular}{ccc}
\hline No & $\begin{array}{c}\text { Waktu } \\
\text { Operasi } \\
\text { Mesin (Jam) }\end{array}$ & $\begin{array}{c}\text { Kehandalan } \\
\text { Part/Komponen (R) }\end{array}$ \\
\hline 1 & 23 & $88.42 \%$ \\
2 & 46 & $78.18 \%$ \\
3 & 69 & $69.12 \%$ \\
4 & 92 & $61.12 \%$ \\
5 & 115 & $54.04 \%$ \\
6 & 138 & $47.78 \%$ \\
7 & 161 & $42.25 \%$ \\
8 & 477 & $7.70 \%$ \\
\hline
\end{tabular}

\section{KESIMPULAN}

Maka dari hasil pembahasan studi analisa penelitian yang dilakukan dimesin DMB yang dilakukan di PT Etex Building Performance Indonesia, didapat beberapa kesimpulan dan hasil dari analisa yang dilakukan oleh peneliti, dan diambil beberapa kesimpulan.

Setelah dilakukan identifikasi menggunakan Failure Mode And Effect Analysis maka didapat berupa penilaian nilai resiko pada setiap kategori baik severity, occurrence, dan detection yang menghasilkan beberapa part yang menjadi prioritas utama resiko berdasarkan kategori dengan menggunakan Tabel FMEA diatas diketahui 
pada komponen/part mesin DMB yang paling sering mengalami kerusakan adalah dengan nilai RPN paling tinggi adalah pada Deccelarator dengan nilai RPN 64, komponen Peunematic dengan nilai 60, Accelarator dengan nilai RPN 56, Hydrolic Table Safety Lock dengan nilai RPN 48, Roller dengan nilai RPN 48, Bearing Lifting dengan nilai RPN 36, Sensor Transfer Dolly dengan nilai RPN 48, sedangkan Motor Transfer Template nilai RPN dengan nilai 36. Suxtion Cup adalah komponen yang memiliki nilai RPN paling rendah dengan nilai 30 , dan dijadikan sebagai prioritas pengecekan dan perawatan saat sedang adanya waktu stop preventif.

Maka dari perhitungan Reliability Block Diagram (RBD) didapat nilai peluang kehandalan mesin DMB sebagai berikut : 88.42 $\%$ apabila proses produksi berjalan selama 23 jam operasi, $42.25 \%$ apabila proses produksi berjalan 161 jam operasi, dan menurun sebesar $7.70 \%$ apabila digunakan selama 477 jam operasi. Ketika keandalan mesin selama proses 23 jam operasi memiliki keandalan sebesar $88.42 \%$ dimana performance atau produktifitas mesin beroperasi waktu proses berlangsung akan semakin menurun dari ke sembilan komponen berpotensi cacat atau komponen tersebut rusak maka saat waktu preventif dari komponen mesin tersebut diwajibkan jadi prioritas utama saat pengecekan ataupun pergantian komponen. Dari hasil penelitian ditarik kesimpulan bahwa apabila semakin tinggi waktu proses produksi maka akan semakin rendah nilai kehandalan dari mesin/komponen tersebut. Maka dari itu saat dilakukan preventif maintenance dapat mengambil langkah yang tepat saat melakukan perbaikan komponen mana saja yang berpotensi menyebabkan stop mesin dan perbaikan disaat proses produksi berlangsung harus segera diperbaiki saat diwaktu preventif.

\section{DAFTAR PUSTAKA}

Harpster, R. A. (2016). How FMEAs can be the cornerstone of ISO 2001: 2015 compliant risk based quality management system. In 2016 Annual Reliability and Maintainability Symposium (RAMS) (pp. 1-5). IEEE.

Jakkula, B., Mandela, G. R., \& SN, M. C. (2020). Reliability block diagram (RBD) and fault tree analysis (FTA) approaches for estimation of system reliability and availability-a case study. International Journal of Quality \& Reliability Management.

Kurniawan, F. (2013). Manajemen perawatan industri. Yogyakarta: Graha Ilmu.

Liu, H. C., You, J. X., Ding, X. F., \& Su, Q. (2015). Improving risk evaluation in FMEA with a hybrid multiple criteria decision smaking method. International Journal of Quality \& Reliability Management.

Pranoto, H. (2015). Reliability Centered Maintenance. Jakarta: Mitra Wacana media.

Rajput, B. S., \& Chourey, V. (2015). Uml based approach for system reliability assessment. International Journal of Computer Applications, 131(2), 09758887.

Rasindyo, M. R., Leksananto, K., \& Helianty, Y. (2015). Analisis Kebijakan Perawatan Mesin Cincinnati Dengan Menggunakan Metode Reliability Centered Maintenance Di Pt. Dirgantara Indonesia. REKA INTEGRA, 3(1).

Ramesh, C. (2012). Antibacterial activity of curcuma longa rhizome extracton pathogenic bacteria.

Yanti, S., Idris, I., Hermawan, I., \& Ibrahim, I. (2018). Estimasi Waktu Perawatan Preventif Mesin Produksi Pada PTPN V SEI Tapung. Jurnal Teknovasi: Jurnal Teknik dan Inovasi, 5(1), 54-65. 